\title{
Associative effects between two fibre sources on ileal and overall digestibilities of amino acids, energy and cell-wall components in growing pigs
}

\author{
BY J.P. LAPLACE AND BEATRICE DARCY-VRILLON \\ Laboratoire de Physiologie de la Nutrition, INRA-Centre de Recherches de Jouy, F-78350 \\ Jouy-en-Josas, France \\ AND J. M. PÉREZ AND Y. HENRY \\ Station de Recherches Porcines, INRA-St Gilles, F-35590 L'Hermitage, France \\ AND SYLVIE GIGER AND D. SAUVANT \\ Station de Nutrition et Alimentation, INA-Paris-Grignon, 16 rue Claude Bernard, F-75231 \\ Paris Cedex 0.5, France
}

(Received 29 December 1987 - Accepted 13 September 1988)

\begin{abstract}
1. The associative effects of two fibre sources on ileal and overall digestibility of amino acids, energy and cellwall components were studied by comparing wheat bran and soya-bean hulls in semi-purified diets given to growing pigs.

2. Castrated male pigs were prepared with ileo-rectal anastomosis to measure ileal digestibility, and overall digestibility was measured in pigs without anastomosis.

3. The three diets contained $190 \mathrm{~g}$ total fibre/kg dry matter (DM), derived from each fibre source or from a mixture of both fibre sources, so that each source provided half the amount of total fibre, and $170 \mathrm{~g}$ crude protein (nitrogen $\times 6.25$ ) $/ \mathrm{kg} \mathrm{DM}$ by additions of casein.

4. The effects of fibre sources on the ileal digestibility of amino acids were additive for most amino acids; the only significant interactions were found for threonine, methionine and aspartic acid. In contrast with ileal digestibility, systematic negative interactions between fibre sources on overall digestibility of amino acids were noted.

5. There was no interaction between fibre sources in their effects on the digestibility of energy or of cell-wall components, irrespective of the site of digestion. The digestibility values were higher with soya-bean hulls than with wheat bran, especially at the faecal level.

6. It is concluded that ileal digestibility of amino acids provides a better estimate of amino acid availability, as ileal measurements allow a better discrimination between diets than faecal measurements when distinct fibre sources are used alone or in combination at the same total fibre content. In contrast, for energy, the measurement of digestibility at both faecal and ileal levels permits the estimation of the partition of available nutrients between the small and large intestines.
\end{abstract}

Dietary fibre in the diets of pigs has been given special attention during recent years (Low, 1985), in particular with regard to its effects on several physiological variables such as gastric emptying (Rainbird, 1986; Rainbird \& Low, 1986a,b), food passage (Sambrook, 1979; Fioramonti \& Bueno, 1980; Kuan et al. 1983; Bardon \& Fioramonti, 1983), fermentation in the large intestine (Argenzio \& Southworth, 1975; Imoto \& Namioka, 1978; Ehle et al. 1982; Varel et al. 1984; Varel, 1987) and cholesterol and bile acid metabolism (Collings et al. 1979). In addition, information has accumulated on the digestion of fibre constituents in the different segments of the gastrointestinal tract (for example, Kass et al. $1980 a, b$ ).

The overall effect of dietary fibre on protein digestion and amino acid availability has been studied (Murray et al. 1977; Dierick et al. 1983; Drochner, 1984). However, there has been little documentation of this effect in relation to the type of fibre used and its chemical composition (Stanogias \& Pearce, 1985a-c; Graham et al. 1986), and the possible 
interactive effects of different fibre sources on amino acid availability have not been evaluated.

Therefore, the present work was designed to study the ileal and overall digestibilities of amino acids and fibrous materials in growing pigs fed on diets containing well-defined fibre sources (wheat bran, soya-bean hulls), either alone or in combination.

\section{MATERIALS AND METHODS}

Diets

Three semi-purified diets based on casein and maize starch were prepared to contain similar amounts of total fibre, originating from either wheat bran (diet B) or soya-bean hulls (diet $\mathrm{H}$ ), or from a mixture of both fibre sources (diet $\mathrm{BH}$ ) so that each source provided half the amount of total fibre. Total fibre, which amounted to about $190 \mathrm{~g} / \mathrm{kg}$ dry matter (DM), was expressed as the sum of analysed cellulose + hemicellulose + uronic acids + acid detergent lignin, according to the methods described on $\mathrm{p}$. 78. In addition to total fibre, the diets contained equivalent amounts of crude protein (nitrogen $\times 6.25 ; 170$ $\mathrm{g} / \mathrm{kg} \mathrm{DM}$ ), total fat and gross energy. The chemical composition of the dietary fibre sources is given in Table 1. The composition of the experimental diets and their chemical characteristics are shown in Table 2 . The contents of amino acids in the three diets are given in Table 3.

Two separate trials were conducted with Large White castrated male growing pigs for overall and ileal digestibility measurements. Both overall and ileal digestibilities are expressed in the conventional way, i.e. (intake-excretion)/intake. Excretion was determined on the basis of total collection of either faeces or ileal digesta.

\section{Ileal digestibility}

The mean initial live weight of the five pigs was 55.4 (SE 3.9) $\mathrm{kg}$ at surgery. Under halothane anaesthesia (Fluothan ${ }^{\circledR}$, Coopers Vétérinaire S.A., Meaux, France) a mid-line incision from the navel to the pubis gave access to the distal digestive tract, to form an end-to-end ileo-rectal anastomosis after total bypass of the entire caeco-colic area as a Thiry loop. The ileum was cut $50 \mathrm{~mm}$ above the ileo-caeco-colic junction and the distal section was closed by a double invagination. The rectum was cut at the level of the pubic bone. A plastic cannula (PVC) was inserted into the proximal section of the caeco-colic area, and fixed by a purse-string suture. The cannula was then exteriorized through a small incision in the right flank of the animal to allow the extracorporeal emptying of residual digesta and gases from the caecum and colon. These segments were thus completely disconnected from the functional gastrointestinal tract. The proximal section of the ileum and the distal section of the rectum were anastomosed end-to-end by individual stitches. However, in most cases, the ileal part had to be cut obliquely in order to compensate for the difference in ileal and rectal diameters. Antibiotics were applied to the peritoneal cavity and two additional intramuscular injections were performed at 48 -h intervals.

This surgical preparation allowed collection of ileal digesta directly excreted via the anus. Under the same general anaesthesia, the pigs' tails were amputated to avoid loss of digesta due to spreading or projection by tail movement. The pigs were adapted to individual housing in metabolism cages. In addition to the usual complete surgical and post-surgical care, specific additional attention included: (1) continuous supplementation of diets by sodium chloride $(5 \mathrm{~g} / \mathrm{kg}$ diet $)$, sodium bicarbonate $(5 \mathrm{~g} / \mathrm{kg}$ diet $)$ and a vitamin mix $(1 \mathrm{~g} / \mathrm{kg}$ diet) (previous experiments confirmed the adequacy of such a supplementation to compensate for the loss of colic function (Laplace et al. 1985 b)); (2) external application of a cream used for human babies (Mitosyl ${ }^{(\mathbb{B}}$ ) to avoid skin irritation due to the increased 
Table 1. Chemical composition of dietary fibre sources ( $\mathrm{g} / \mathrm{kg}$ dry matter (DM))

\begin{tabular}{|c|c|c|}
\hline & \multicolumn{2}{|c|}{ Dietary fibre source } \\
\hline & Wheat bran & $\begin{array}{c}\text { Soya-bean } \\
\text { hulls }\end{array}$ \\
\hline $\mathrm{DM}(\mathrm{g} / \mathrm{kg}$ diet $)$ & 871 & 881 \\
\hline Organic matter & 929 & 952 \\
\hline Crude protein (nitrogen $\times 6.25$ ) & 150 & 120 \\
\hline Diethyl ether extract & 39 & 20 \\
\hline Gross energy (MJ/kg DM) & $19 \cdot 46$ & $18 \cdot 33$ \\
\hline Crude fibre & 123 & 385 \\
\hline Neutral-detergent fibre & 454 & 641 \\
\hline Acid-detergent fibre & 141 & 450 \\
\hline Acid-detergent lignin & 35 & 20 \\
\hline Hemicellulose* & 257 & 210 \\
\hline Cellulose* & 101 & 306 \\
\hline Uronic acids $\dagger$ & - & 61 \\
\hline Total fibret & 393 & 597 \\
\hline \multicolumn{3}{|c|}{ Individual monosaccharides in hemicellulose* and cellulose* fractions } \\
\hline Rhamnose & 1 & 5 \\
\hline Arabinose & 100 & 50 \\
\hline Xylose & 142 & 77 \\
\hline Mannose & 4 & 53 \\
\hline Galactose & 10 & 25 \\
\hline Glucose & 101 & 306 \\
\hline
\end{tabular}

* Determined by gas-liquid chromatography according to Sawardeker et al. (1965).

$\uparrow$ Determined according to El Rayah \& Labavitch (1977).

$\ddagger$ Cellulose + hemicellulose + uronic acids + acid-detergent lignin.

emission of digesta which were more liquid and acid than normal faeces. The colic cannula was kept clean several times daily until all residual colic contents were emptied. During the $8 \mathrm{~d}$ post-operative period, the pigs were fed on a standard diet containing the following amounts of ingredients $(\mathrm{g} / \mathrm{kg}$ diet): barley 600 , maize 150 , soya-bean meal 150 , lucerne (Medicago sativa) meal 65, minerals and vitamins 35 . The crude protein and crude fibre contents (g/kg DM) were 159 and 67 respectively. The experimental period lasted 3 weeks, each pig being given the three diets consecutively in the following order: $\mathrm{B}, \mathrm{H}, \mathrm{BH}$, with $4 \mathrm{~d}$ of adaptation and $3 \mathrm{~d}$ of collection for each diet. During the three experimental weeks, the pigs received $2 \mathrm{~kg}$ fresh food daily as two equal meals at 09.00 and 16.00 hours. The feed was mixed with water ( 1 part meal +2 parts water). Water was given ad lib.

The excreted digesta were collected twice daily. After homogenization of the digesta collected over $24 \mathrm{~h}$, a sample (10\% of the total wet weight) was taken for determination of DM, nitrogen and gross energy. In addition, a representative sample of the $72 \mathrm{~h}$ collection was taken for each pig on each diet to determine amino acid and fibre contents.

\section{Overall digestibility}

Overall digestibility measurements were performed with eighteen pigs which were allocated to the three treatments (six pigs/diet) according to a completely randomized block design, taking age and live weight into account. After a $14 \mathrm{~d}$ adaptation period in digestibility crates, a total faecal collection was made during a $10 \mathrm{~d}$ period after the pigs reached a mean initial live weight of 47.9 (SE 3.0) $\mathrm{kg}$. The level of feeding was adjusted to the initial live weight and was maintained constant during the entire collection period. The average daily 
Table 2. Ingredients $(\mathrm{g} / \mathrm{kg}$ diet $)$ in the experimental diets and their chemical composition $(\mathrm{g} / \mathrm{kg}$ dry matter $(D M))$

\begin{tabular}{|c|c|c|c|}
\hline & \multicolumn{3}{|c|}{ Diet } \\
\hline & B & BH & $\mathrm{H}$ \\
\hline \multicolumn{4}{|l|}{ Ingredients } \\
\hline Wheat bran & $484 \cdot 5$ & $242 \cdot 2$ & $\ldots$ \\
\hline Soya-bean hulls & - & $166 \cdot 0$ & $332 \cdot 0$ \\
\hline Casein (hydrochloride) & $103 \cdot 0$ & $119 \cdot 7$ & $136 \cdot 3$ \\
\hline Maize starch & $357 \cdot 5$ & $412 \cdot 1$ & $465 \cdot 7$ \\
\hline Maize oil & $20 \cdot 0$ & $25 \cdot 0$ & $31 \cdot 0$ \\
\hline Mineral and vitamin mixture* & $35 \cdot 0$ & $35 \cdot 0$ & $35 \cdot 0$ \\
\hline \multicolumn{4}{|l|}{ Chemical composition } \\
\hline DM & 884 & 883 & 888 \\
\hline Organic matter & 934 & 945 & 956 \\
\hline Crude fibre & 58 & 98 & 127 \\
\hline Neutral-detergent fibre & 228 & 229 & 217 \\
\hline Acid-detergent fibre & 71 & 112 & 148 \\
\hline Acid-detergent lignin & 21 & 15 & 8 \\
\hline Total fibre $\dagger$ & 190 & 194 & 198 \\
\hline Crude protein (nitrogen $\times 6 \cdot 25$ ) & 171 & 169 & 171 \\
\hline Diethyl ether extract & 44 & 43 & 41 \\
\hline Gross energy (MJ/kg DM) & $19 \cdot 04$ & $19 \cdot 20$ & $19 \cdot 12$ \\
\hline
\end{tabular}

* Supplying the following quantities $(/ \mathrm{kg}$ diet): dicalcium phosphate $10 \mathrm{~g}$, calcium carbonate $4.5 \mathrm{~g}$, sodium chloride $3.0 \mathrm{~g}$, potassium chloride $4.0 \mathrm{~g}$, magnesium carbonate $2.0 \mathrm{~g}$, ferrous sulphate heptahydrate $50 \mathrm{mg}$, manganese sulphate pentahydrate $16 \mathrm{mg}$, copper sulphate pentahydrate $4 \mathrm{mg}$, zinc sulphate heptahydrate $44 \mathrm{mg}$, potassium iodide $45 \mu \mathrm{g}$, sodium selenite $60 \mu \mathrm{g}$, retinol $1.5 \mathrm{mg}$, cholecalciferol $25 \mu \mathrm{g}$, $\alpha$-tocopherol $28 \mathrm{mg}$, menadione $4.4 \mathrm{mg}$, thiamin hydrochloride $3.0 \mathrm{mg}$, riboflavin $6.0 \mathrm{mg}$, nicotinic acid $36 \mathrm{mg}$, calcium pantothenate $30 \mathrm{mg}$, pyridoxine hydrochloride $3.0 \mathrm{mg}$, pteroylmonoglutamic acid $2.0 \mathrm{mg}$, meso-inositol $200 \mathrm{mg}$, $p$-aminobenzoic acid $20 \mathrm{mg}$, biotin $3.0 \mu \mathrm{g}$, cyanocobalamin $30 \mu \mathrm{g}$, choline chloride $1.5 \mathrm{~g}$.

$\dagger$ Calculated from the chemical analyses of dietary fibre sources : cellulose + hemicellulose + uronic acids + aciddetergent lignin.

feed supply was $2 \mathrm{~kg}(1.76 \mathrm{~kg} \mathrm{DM})$. The diets were offered twice daily in wet form ( 2 parts water +1 part meal) as in the previous trial. Faeces were collected twice daily and stored at $+1^{\circ}$.

\section{Chemical analyses}

The determinations of DM, ash and $\mathrm{N}$ (Kjeldahl) in feeds were made according to conventional methods. Gross energy content was measured with an adiabatic bomb calorimeter. Fat content was analysed with a Soxhlet-type semi-automatic apparatus (Soxtec). Amino acid analyses were made by ion-exchange chromatography as outlined by Pion \& Fauconneau (1966). The contents of cell-wall components were determined with the following methods: crude fibre (EEC official method), neutral-detergent fibre (NDF), aciddetergent fibre (ADF) and acid-detergent lignin (ADL), according to the procedure described by Van Soest (1963), Van Soest \& Wine (1967), and adapted by Giger et al. $(1987 \mathrm{~b}$ ). Individual cell-wall monosaccharides liberated by acid-hydrolysis (Saeman et al. 1954) were analysed by gas-liquid chromatography of their alditol acetates (Sawardeker et al. 1965). Cell-wall uronide content was determined in fibrous sources according to the method of El Rayah \& Labavitch (1977).

\section{Statistical analysis}

The methodology used to test digestive interactions has been fully described elsewhere by Giger et al. (1987a). Briefly, the method involved two steps. First, the 'diet' effect was 
Table 3. Amino acid composition of experimental diets* ( $\mathrm{g} / \mathrm{kg}$ dry matter)

\begin{tabular}{|c|c|c|c|}
\hline & \multicolumn{3}{|c|}{ Dietary fibre source } \\
\hline & $\begin{array}{l}\text { Wheat } \\
\text { bran }\end{array}$ & $\begin{array}{l}\text { Wheat bran and } \\
\text { soya-bean hulls } \dagger\end{array}$ & $\begin{array}{c}\text { Soya-bean } \\
\text { hulls }\end{array}$ \\
\hline Sum of seventeen amino acids & $175 \cdot 0$ & $177 \cdot 0$ & $185 \cdot 0$ \\
\hline \multicolumn{4}{|l|}{ Essential amino acids } \\
\hline Lysine & $10 \cdot 8$ & $11 \cdot 6$ & $13 \cdot 0$ \\
\hline Methionine & $3 \cdot 3$ & $3 \cdot 8$ & $3 \cdot 8$ \\
\hline Cystine & $2 \cdot 4$ & 1.9 & $1 \cdot 6$ \\
\hline Threonine & $7 \cdot 5$ & $7 \cdot 2$ & $7 \cdot 9$ \\
\hline Isoleucine & $8 \cdot 0$ & $8 \cdot 1$ & $8 \cdot 8$ \\
\hline Leucine & $14-3$ & $14 \cdot 4$ & $15 \cdot 3$ \\
\hline Histidine & $5-4$ & $5 \cdot 2$ & $5 \cdot 4$ \\
\hline Valine & $11 \cdot 2$ & $11 \cdot 0$ & $11 \cdot 4$ \\
\hline Phenylalanine & $8 \cdot 3$ & $8 \cdot 2$ & $8 \cdot 9$ \\
\hline Tyrosine & $8 \cdot 3$ & $8 \cdot 8$ & $9 \cdot 9$ \\
\hline Arginine & $9 \cdot 7$ & $8 \cdot 3$ & $7 \cdot 7$ \\
\hline \multicolumn{4}{|l|}{ Non-essential amino acids } \\
\hline Glutamic acid + glutamine & $35 \cdot 7$ & $33 \cdot 9$ & $34 \cdot 3$ \\
\hline Aspartic acid + asparagine & $12 \cdot 2$ & $12 \cdot 1$ & 11.6 \\
\hline Serine & 8.9 & $9 \cdot 2$ & 100 \\
\hline Proline & $16 \cdot 5$ & $15 \cdot 5$ & $17 \cdot 1$ \\
\hline Glycine & $6 \cdot 1$ & $5 \cdot 9$ & $6 \cdot 2$ \\
\hline Alanine & $6 \cdot 7$ & $6 \cdot 1$ & $6 \cdot 1$ \\
\hline
\end{tabular}

* For details, see Tables 1 and 2.

$\dagger$ Each fibre source provided half the amount of total fibre.

tested by an analysis of variance also taking into account any 'animal' effect. For repeated measurements, it was also possible to test the 'animal' $x$ 'diet' interaction. If there was no 'diet' effect, there was no digestive interaction. If a significant 'diet' effect was found, it was necessary to use a regression method as a second step, as described by Giger \& Sauvant (1983). The residual sums of squares obtained from the variance analysis and from the regression were compared by using the Fisher test (Snedecor \& Cochran, 1967). By demonstrating a non-linear regression, this procedure allowed the existence of any digestive interaction to be shown.

\section{RESULTS}

\section{Protein and amino acid digestibility}

There were no significant differences between animals in the ileal digestibility measurements for amino acids and total $\mathrm{N}$. As appears from the results given in Table 4, the digestibility of total $\mathrm{N}$ and of the sum of amino acids was not significantly affected $(P>0.05)$ by diet composition. Diet effect, depending on the origin of cell-wall components, was significant for ten of the seventeen amino acids. For only three of them was there a significant interaction between fibre sources, which was positive for methionine and aspartic acid and negative for threonine. In addition to these three amino acids, digestibility values for cystine, histidine tyrosine, serine, glycine and aspartic acid were higher with diet $B$ (wheat bran) than with diet $\mathrm{H}$ (soya-bean hulls). Conversely, amino acid digestibility was lower with diet $\mathrm{B}$ for leucine, phenylalanine, methionine and threonine.

The results of overall digestibility are reported in Table 5. There was only a small difference between diets $\mathrm{B}$ and $\mathrm{H}$. The statistical importance of the overall diet effect is essentially explained by the association between the two dietary fibre sources (wheat bran 
Table 4. Ileal apparent digestibility of crude protein (nitrogen $\times 6 \cdot 25)$ and amino acids of experimental diets $\dagger$

(Mean values and standard deviations)

\begin{tabular}{|c|c|c|c|c|c|c|c|c|}
\hline & \multicolumn{6}{|c|}{ Dietary fibre source } & \multicolumn{2}{|c|}{$\begin{array}{c}\text { Statistical } \\
\text { significance of }\end{array}$} \\
\hline & \multirow{2}{*}{\multicolumn{2}{|c|}{ Wheat bran }} & \multirow{2}{*}{\multicolumn{2}{|c|}{$\begin{array}{l}\text { Wheat bran and } \\
\text { soya-bean hulls } \ddagger\end{array}$}} & \multirow{2}{*}{\multicolumn{2}{|c|}{ Soya-bean hulls }} & \multirow{3}{*}{$\begin{array}{l}\text { Treat- } \\
\text { ment } \\
\text { effect }\end{array}$} & \multirow{3}{*}{$\begin{array}{l}\text { Non- } \\
\text { linear } \\
\text { effect }\end{array}$} \\
\hline & & & & & & & & \\
\hline & Mean & $\mathrm{SD}$ & Mean & SD & Mean & SD & & \\
\hline Crude protein & 0.808 & $0-011$ & 0.807 & $0 \cdot 008$ & 0.800 & 0.003 & NS & \\
\hline Sum of seventeen amino acids & $0 \cdot 850$ & 0.009 & 0.850 & 0.008 & $0 \cdot 843$ & 0.006 & NS & \\
\hline \multicolumn{9}{|l|}{ Essential amino acids } \\
\hline Lysine & $0 \cdot 866$ & 0.011 & 0.858 & 0.006 & 0.856 & 0.004 & NS & \\
\hline Methionine & $0 \cdot 887$ & 0.004 & 0.914 & 0.004 & $0 \cdot 906$ & 0.009 & $* * *$ & $* *$ \\
\hline Cystine & 0.682 & 0.017 & 0.627 & 0.019 & 0.536 & 0.019 & $* * *$ & NS \\
\hline Threonine & $0 \cdot 800$ & $0 \cdot 016$ & 0.798 & 0.014 & $0 \cdot 827$ & 0.004 & $* *$ & $*$ \\
\hline Isoleucine & $0 \cdot 844$ & $0-008$ & 0.844 & 0.010 & 0.832 & $0 \cdot 014$ & NS & \\
\hline Leucine & 0.863 & $0-007$ & 0.874 & 0.006 & 0.875 & 0.007 & $*$ & NS \\
\hline Histidine & 0.871 & 0.006 & 0.860 & 0.009 & 0.861 & 0.005 & $*$ & NS \\
\hline Valine & 0.839 & $0 \cdot 007$ & 0.841 & 0.009 & 0.836 & 0.009 & NS & \\
\hline Phenylalanine & 0.864 & $0-005$ & 0.872 & 0.008 & 0.881 & 0.008 & $* *$ & NS \\
\hline Tyrosine & 0.885 & 0.007 & 0.875 & 0.004 & 0.866 & 0.010 & $* *$ & NS \\
\hline Arginine & 0.856 & $0-013$ & 0.850 & 0.009 & 0.850 & 0.008 & NS & \\
\hline \multicolumn{9}{|l|}{ Non-essential amino acids } \\
\hline Glutamic acid + glutamine & $0 \cdot 888$ & $0 \cdot 016$ & 0.889 & 0.009 & $0 \cdot 887$ & 0.008 & NS & \\
\hline Aspartic acid + asparagine & 0.817 & 0.009 & 0.812 & 0.008 & 0.779 & $0 \cdot 007$ & $* * *$ & $* *$ \\
\hline Serine & 0.831 & 0.013 & 0.800 & 0.017 & 0.761 & 0.022 & $* *$ & NS \\
\hline Proline & 0.903 & $0-013$ & 0.896 & 0.011 & 0.890 & 0.006 & NS & \\
\hline Glycine & 0.670 & $0 \cdot 026$ & 0.587 & 0.017 & 0.542 & 0.011 & $* * *$ & NS \\
\hline Alanine & 0.742 & $0-011$ & 0.741 & 0.012 & 0.739 & 0.007 & NS & \\
\hline
\end{tabular}

NS, not significant.

* $P<0.05$, ** $P<0.01, * * * P<0.005$.

+ For details, see Tables 1-3.

$\ddagger$ Each fibre source provided half the amount of total fibre.

and soya-bean hulls) which resulted in a systematic negative interaction ( -3 points on average) for all the amino acids, especially in the case of threonine ( -5 points). The same phenomenon was observed for crude protein and for the sum of the seventeen amino acids.

\section{Digestibility of energy and cell-wall components}

As shown in Table 6, for all variables there was no animal effect on ileal digestibility and no block effect on overall digestibility. In addition, no interaction was observed. The diet effect was significant, with uniformly higher digestibility values in diet $\mathbf{H}$ than in diet $\mathbf{B}$. This difference between the two diets was particularly important at the faecal level.

The calculation of the digestibility of the dietary non-nitrogenous cellular fraction indicates a slightly but significantly lower $(P<0.01)$ digestibility at the terminal ileum with soya-bean hulls (diet $\mathrm{H}$ ), while the opposite effect, moderate but significant $(P<0.05)$, was observed for overall digestibility. On the whole, this corresponded to a significantly higher ileal digestibility of organic matter and energy in diet $\mathrm{H}$ containing soya-bean hulls. 
Table 5. Overall apparent digestibility of crude protein (nitrogen $\times 6.25)$ and amino acids of experimental diets $\dagger$

(Mean values and standard deviations)

\begin{tabular}{|c|c|c|c|c|c|c|c|c|}
\hline & \multicolumn{6}{|c|}{ Dietary fibre source } & \multirow{2}{*}{\multicolumn{2}{|c|}{$\begin{array}{c}\text { Statistical } \\
\text { significance of }\end{array}$}} \\
\hline & \multirow{2}{*}{\multicolumn{2}{|c|}{ Wheat bran }} & \multirow{2}{*}{\multicolumn{2}{|c|}{$\begin{array}{l}\text { Wheat bran and } \\
\text { soya-bean hulls }\end{array}$}} & \multirow{2}{*}{\multicolumn{2}{|c|}{ Soya-bean hulls }} & & \\
\hline & & & & & & & \multirow{2}{*}{$\begin{array}{l}\text { Treat- } \\
\text { ment } \\
\text { effect }\end{array}$} & \multirow{2}{*}{$\begin{array}{l}\text { Non- } \\
\text { linear } \\
\text { effect }\end{array}$} \\
\hline & Mean & SD & Mean & SD & Mean & SD & & \\
\hline Crude protein & 0.872 & 0.015 & 0835 & $0 \cdot 019$ & $0 \cdot 864$ & $0 \cdot 006$ & $* *$ & $* *$ \\
\hline Sum of seventeen amino acids & $0 \cdot 895$ & $0 \cdot 015$ & 0.867 & $0 \cdot 014$ & 0.890 & 0.006 & ** & $* *$ \\
\hline \multicolumn{9}{|l|}{ Essential amino acids } \\
\hline Lysine & $0 \cdot 884$ & $0 \cdot 017$ & 0.858 & 0.022 & 0.887 & $0 \cdot 011$ & $*$ & $* *$ \\
\hline Methionine & 0.867 & 0.019 & $0 \cdot 843$ & $0 \cdot 015$ & 0.883 & 0.009 & $* * *$ & $* * *$ \\
\hline Cystine & 0.806 & 0.023 & 0.743 & 0.024 & 0.746 & 0.009 & $* * *$ & $* * *$ \\
\hline Threonine & 0.855 & $0 \cdot 022$ & $0 \cdot 804$ & $0 \cdot 020$ & $0 \cdot 858$ & 0.005 & $* * *$ & $* * *$ \\
\hline Isoleucine & 0.874 & 0.023 & 0.845 & $0 \cdot 018$ & 0.877 & 0.009 & $*$ & $* * *$ \\
\hline Leucine & 0.894 & 0.013 & 0.870 & 0.013 & 0.902 & 0.006 & $* * *$ & $* * *$ \\
\hline Histidine & 0.921 & 0.010 & 0896 & 0.016 & 0.907 & 0.007 & $* *$ & $* *$ \\
\hline Valine & 0.885 & 0.017 & 0.860 & 0.018 & 0.888 & 0.009 & * & $* * *$ \\
\hline Phenylalanine & 0.889 & 0.015 & 0.853 & 0.014 & 0.886 & 0.006 & $* * *$ & $* * *$ \\
\hline Tyrosine & 0.905 & $0 \cdot 013$ & 0.877 & 0.012 & 0.898 & 0.008 & $* * *$ & $* * *$ \\
\hline Arginine & 0.897 & $0 \cdot 015$ & 0.862 & $0 \cdot 015$ & 0.887 & $0 \cdot 010$ & $* * *$ & $* * *$ \\
\hline \multicolumn{9}{|l|}{ Non-essential amino acids } \\
\hline Glutamic acid + glutamine & 0.941 & $0-009$ & 0918 & $0 \cdot 010$ & 0.932 & 0.004 & $* * *$ & $* * *$ \\
\hline Aspartic acid + asparagine & $0 \cdot 840$ & $0 \cdot 023$ & 0.795 & 0.022 & 0.821 & 0.011 & $* * *$ & $* * *$ \\
\hline Serine & 0.898 & 0.014 & 0.864 & $0 \cdot 012$ & 0.882 & $0 \cdot 004$ & $* * *$ & $* * *$ \\
\hline Proline & 0.952 & 0.006 & 0.938 & 0.006 & 0.946 & 0.003 & $* * *$ & $* * *$ \\
\hline Glycine & 0.806 & $0 \cdot 024$ & 0693 & 0.025 & 0.699 & $0 \cdot 011$ & $* * *$ & $* * *$ \\
\hline Alanine & $0 \cdot 805$ & $0 \cdot 017$ & 0.740 & 0.030 & 0.778 & $0 \cdot 010$ & $* * *$ & $* * *$ \\
\hline
\end{tabular}

NS, not significant.

*. $P<0.05, * * P<0.01, * * * P<0.005$.

$\uparrow$ For details, see Tables 1-3.

$\mp$ Each fibre source provided half the amount of total fibre.

\section{Ileal $\mathrm{v}$. overall digestibility}

Except for one amino acid (phenylalanine) (see Table 7) the digestibility coefficients of all dietary components (energy and $\mathrm{N}$ as well) were significantly affected by the site of digesta collection (ileum $v$. faeces). For all these components, there was a significant interaction between treatment and collection site, except for three amino acids (lysine, histidine, proline).

\section{DISCUSSION}

With regard to the methodological approach, two points need to be considered: the choice of ileo-rectal anastomosis and the design of experimental diets.

The ileo-rectal anastomosis has been used in the past few years concurrently with various techniques based on ileal fistulation: i.e. ' $T$ '-shaped, re-entrant or ileo-colic-post-valvular fistulation (Laplace et al. 1985 b). This procedure became widely used relatively quickly, since the surgical preparation of an ileo-rectal anastomosis and the collection of digesta are very easy compared with fistulation techniques. In addition, the ileo-rectal anastomosis is well tolerated for long-term periods. Despite these advantages, the possible consequences 
Table 6. Ileal and overall digestibilities of non-nitrogenous components of experimental diets $\dagger$

(Mean values and standard deviations)

\begin{tabular}{|c|c|c|c|c|c|c|c|c|}
\hline & \multicolumn{6}{|c|}{ Dietary fibre source } & \multicolumn{2}{|c|}{$\begin{array}{c}\text { Statistical } \\
\text { significance of }\end{array}$} \\
\hline & \multirow{2}{*}{\multicolumn{2}{|c|}{ Wheat bran }} & \multirow{2}{*}{\multicolumn{2}{|c|}{$\begin{array}{l}\text { Wheat bran and } \\
\text { soya-bean hulls }\end{array}$}} & \multirow{2}{*}{\multicolumn{2}{|c|}{ Soya-bean hulls }} & \multirow{3}{*}{$\begin{array}{l}\text { Treat- } \\
\text { ment } \\
\text { effect }\end{array}$} & \\
\hline & & & & & & & & \multirow{2}{*}{$\begin{array}{l}\text { Non- } \\
\text { linear } \\
\text { effect }\end{array}$} \\
\hline & Mean & SD & Mean & SD & Mean & SD & & \\
\hline \multicolumn{9}{|l|}{ Ileal digestibility (five pigs) } \\
\hline Dry matter & 0.647 & 0.022 & 0.658 & 0.014 & $0 \cdot 681$ & 0.027 & $* *$ & NS \\
\hline Organic matter $(\mathrm{OM})$ & 0.678 & 0012 & 0.681 & 0.008 & $0 \cdot 703$ & 0.007 & $* *$ & NS \\
\hline Gross energy & 0.675 & 0.021 & 0.691 & 0.014 & 0.713 & 0.025 & ** & NS \\
\hline Crude fibre & -0.014 & 0.027 & 0.050 & 0.031 & 0.044 & 0.022 & ** & NS \\
\hline Neutral-detergent fibre (NDF) & $0-060$ & 0.033 & 0.093 & 0.023 & $0 \cdot 152$ & $0 \cdot 025$ & $* *$ & NS \\
\hline Acid-detergent fibre & 0.051 & 0.033 & 0.033 & 0.030 & 0.039 & 0.023 & NS & \\
\hline OM-Sum AA-NDF $\&$ & 0.887 & $0 \cdot 007$ & 0.875 & 0.007 & $0 \cdot 871$ & 0.006 & $* *$ & NS \\
\hline \multicolumn{9}{|l|}{ Overall digestibility (six pigs) } \\
\hline Dry matter & 0.778 & $0 \cdot 007$ & 0.821 & 0.023 & 0.877 & 0.013 & $* * *$ & NS \\
\hline Organic matter (OM) & 0.800 & 0.007 & 0.837 & 0.021 & $0 \cdot 888$ & 0.013 & $* *$ & NS \\
\hline Gross energy & 0.785 & 0.008 & 0.825 & 0.022 & 0.878 & 0.013 & $* *$ & NS \\
\hline Crude fibre & $0 \cdot 235$ & 0.026 & 0.543 & 0.134 & 0.688 & 0.074 & $* * *$ & NS \\
\hline Neutral-detergent fibre (NDF) & $0 \cdot 393$ & $0 \cdot 013$ & 0.564 & 0.084 & 0.731 & 0.048 & $* * *$ & NS \\
\hline Acid-detergent fibre & $0 \cdot 213$ & 0.027 & 0.518 & $0 \cdot 139$ & $0 \cdot 690$ & 0.068 & $* * *$ & NS \\
\hline OM-Sum AA-NDF\& & 0.940 & 0.006 & 0.942 & 0.003 & 0.948 & $0 \cdot 004$ & $*$ & NS \\
\hline
\end{tabular}

NS, not significant; AA, amino acids.

* $P<0.05$, ** $P<0.01$, *** $P<0.005$.

$\dagger$ For details, see Tables 1-3.

$\$$ Each fibre source provided half the amount of total fibre.

$\S$ Non-nitrogenous cellular content; Sum AA $=$ sum of seventeen amino acids.

of the ileo-rectal anastomosis have not been fully evaluated, as pointed out by Laplace et al. $(1985 b)$ : hydro-electrolytic disturbances and vitamin deficiencies due to the bypass of the colon, reduced energy supplies due to the absence of colic fermentation, possible adaptations or changes in digestive and absorptive functions in long-term experiments, as well as possible hepatic dysfunctions or metabolic disorders which are well known to occur after small intestine resection or bypass (Laplace, 1975). In the present experiments, the problems mentioned previously have been treated in the following manner: the animals were given supplementary electrolytes and vitamins; the measured weight gain appeared within normal limits despite the absence of colic fermentation; the entire experiment was completed within 4 weeks following the operation, thus avoiding any long-term digestive or metabolic changes. Consequently, the period of adaptation to experimental diets was reduced to $4 \mathrm{~d}$, which may seem brief. However, it should be underlined that bypassing the colon takes out the part of the intestinal tract which needs the longest time to clear residues of previous diets. In pigs after ileo-rectal anastomosis, $4 \mathrm{~d}$ are sufficient for renewing the contents of the stomach and small intestine (Laplace, 1981). Finally, the ileo-rectal anastomosis provides a particular advantage in the case of high-fibre diets, by avoiding possible blockage of cannulas and consequent erroneous estimates of food passage and digestibility.

The diets were designed to contain the same amounts of total fibre, crude protein and gross energy. Since the two fibre sources differed in their crude protein contents, this resulted in some difference in the level of casein incorporation, so that the proportion of 
Table 7. Effects of the site of digesta collection and of its interaction with the treatment (diets) on the digestibility of dietary components

\begin{tabular}{|c|c|c|c|c|}
\hline & \multicolumn{3}{|c|}{ Statistical significance of effects } & \multirow[b]{2}{*}{$\begin{array}{c}\text { Pooled } \\
\text { SE }\end{array}$} \\
\hline & $\begin{array}{l}\text { Site of } \\
\text { digesta } \\
\text { collection }\end{array}$ & Treatment & $\begin{array}{l}\text { Interaction } \\
\text { site } \times \\
\text { treatment }\end{array}$ & \\
\hline Crude protein (nitrogen $\times 6.25$ ) & $* * *$ & $* *$ & ** & $0 \cdot 012$ \\
\hline Sum of seventeen amino acids & $* * *$ & * & $*$ & 0.010 \\
\hline $\begin{array}{l}\text { Essential amino acids } \\
\text { Lysine } \\
\text { Methionine } \\
\text { Cystine } \\
\text { Threonine } \\
\text { Isoleucine } \\
\text { Leucine } \\
\text { Histidine } \\
\text { Valine } \\
\text { Phenylalanine } \\
\text { Tyrosine } \\
\text { Arginine }\end{array}$ & $\begin{array}{l}* * * \\
* * * \\
* * * \\
* * * \\
* * * \\
* * * \\
* * * \\
* * * \\
\mathrm{NS} \\
* * * \\
* * *\end{array}$ & $\begin{array}{l}* \\
* * \\
* * * \\
* * * \\
\mathrm{NS} \\
* * * \\
* * * \\
\mathrm{NS} \\
* * * \\
* * * \\
* * *\end{array}$ & $\begin{array}{r}\mathrm{NS} \\
* * * \\
* * * \\
* * \\
* \\
* * * \\
\mathrm{NS} \\
* \\
* * * \\
* * \\
*\end{array}$ & $\begin{array}{l}0.014 \\
0.012 \\
0.020 \\
0.015 \\
0.015 \\
0 \cdot 010 \\
0.010 \\
0 \cdot 013 \\
0 \cdot 010 \\
0.010 \\
0.012\end{array}$ \\
\hline $\begin{array}{l}\text { Non-essential amino acids } \\
\text { Glutamic acid + glutamine } \\
\text { Aspartic acid + asparagine } \\
\text { Serine } \\
\text { Proline } \\
\text { Glycine } \\
\text { Alanine }\end{array}$ & $\begin{array}{r}* * * \\
* * * \\
* * * \\
* * * \\
* * *\end{array}$ & $\begin{array}{r}\text { NS } \\
* * * \\
* * * \\
* \\
* * * \\
* *\end{array}$ & $\begin{array}{r}* \\
* * * \\
* * * \\
\mathrm{NS} \\
* \\
* *\end{array}$ & $\begin{array}{l}0.010 \\
0 \cdot 015 \\
0 \cdot 014 \\
0.008 \\
0.020 \\
0 \cdot 020\end{array}$ \\
\hline $\begin{array}{l}\text { Non-nitrogenous components } \\
\text { Dry matter } \\
\text { Organic matter (OM) } \\
\text { Gross energy } \\
\text { Crude fibre } \\
\text { Neutral-detergent fibre (NDF) } \\
\text { Acid-detergent fibre } \\
\text { OM-Sum AA-NDF } \dagger\end{array}$ & $\begin{array}{l}* * * \\
* * * \\
* * * \\
* * * \\
* * \\
* * * \\
* * *\end{array}$ & $\begin{array}{r}* * \\
* * \\
* * * \\
* * \\
* * \\
* * * \\
\text { NS }\end{array}$ & $\begin{array}{r}* * \\
* * \\
* * \\
* * \\
* * \\
* * * \\
* *\end{array}$ & $\begin{array}{l}0.013 \\
0.014 \\
0.037 \\
0.069 \\
0.046 \\
0.070 \\
0.006\end{array}$ \\
\hline
\end{tabular}

NS, not significant.

* $P<0.05$, ** $P<0.01$, *** $P<0.005$.

$\dagger$ Non-nitrogenous cellular content; Sum AA $=$ sum of seventeen amino acids.

dietary protein from casein in total protein was $0.57,0.68$ and 0.75 in diets $\mathrm{B}, \mathrm{BH}$ and $\mathrm{H}$ respectively. In diet $\mathbf{H}$ the lower digestibility of protein in soya-bean hulls compared with wheat bran (Institut National de la Recherche Agronomique, 1984) was compensated by a higher dietary content of highly-digestible protein in the form of casein. Therefore, there was little difference in protein and amino acid digestibility between diets $\mathrm{B}$ and $\mathrm{H}$ at ileal and faecal levels. Nevertheless, since the experiment was focused on the interactions between fibre sources, it was necessary to formulate the diets on the basis of the same overall fibre content. Notwithstanding, this shows the difficulty of interpreting the effects of cell-wall polysaccharides on amino acid digestibility with fibrous feeds containing different proportions of protein. On the other hand, the equilibration of dietary energy contents resulted in a slight increase in the levels of maize starch and oil with the increasing level of soya-bean hulls. This provides a partial explanation of the higher ileal digestibility of energy in diet $\mathbf{H}$. 
From previous results using ileal-fistulated pigs, there is clear evidence that amino acid ileal digestibility allows a better discrimination between diets than overall digestibility, as reported by Low (1982), Tanksley \& Knabe (1984) and Laplace et al. (1985b). This observation is confirmed in the present work which was based on ileo-rectal anastomosis with pigs given diets containing two distinct fibre sources alone or in combination at the same total dietary fibre content. In addition, it was clearly demonstrated in the present study that the association of different fibre sources resulted in a highly significant negative interaction with the overall digestibility of amino acids, while additive effects were observed in most cases at the end of the small intestine. The notable depression of overall amino acid digestibility in pigs fed on diet $\mathrm{BH}$ could have resulted from two possible effects: (1) a stimulation of bacterial growth in the large intestine, responsible for an increased microbial protein synthesis; (2) an increased flow of endogenous $\mathrm{N}$ originating from digestive secretions and cell-wall desquamation.

The fibre fraction originating from soya-bean hulls could be responsible for the first effect. Indeed, the difference between overall and ileal digestibility coefficients for diet $\mathbf{H}$ shows that a larger amount of NDF from soya-bean hulls than from wheat bran is fermented in the large intestine. Compared with wheat bran, soya-bean hulls contain a fairly high amount of pectins which have been shown to increase microbial protein synthesis in the large intestine (Rotenberg et al. 1982). However, if this was the only mechanism for a reduced $\mathrm{N}$ apparent digestibility of diet $\mathrm{BH}$, this would lead to an even larger effect, i.e. a lower digestibility with diet $\mathrm{H}$, and this was not observed.

The second possible effect also needs careful examination. Both quantity (Ecknauer $e t a l$. 1981) and quality (Jacobs, 1983) of fibre are known to affect the various components of cellwall proliferation in the small intestine as well as in the colon (Jacobs \& Schneeman, 1981). In addition, fibre effects on digestive secretions have been seen, mainly in the case of pancreatic secretion (Schneeman et al. 1982; Langlois et al. 1987). However, if there was an increased flow of endogenous $\mathrm{N}$ into the small intestine, either from the pancreatic flow due to wheat bran (36\% increase of daily protein output according to Langlois et al. 1987) or from the mucosa of the small intestine, this did not result in a lower ileal $\mathrm{N}$ apparent digestibility (diet $\mathrm{B} v$. diet $\mathrm{H}$ or $\mathrm{BH}$ ). Therefore, if an increased flow of endogenous $\mathrm{N}$ was involved in the depression of overall digestibility of amino acids, it could only take place in the colon. Nevertheless, if such a bran effect was responsible for a reduced $\mathrm{N}$ apparent digestibility of diet $\mathrm{BH}$, this would lead to an even larger effect, i.e. a lower digestibility, with diet $\mathrm{B}$, and this was not observed. Thus neither of the two factors considered above seems to be sufficient in itself to explain the negative interaction of fibre-mixing on overall digestibility.

The proportions in which additional faecal amino acids were excreted with diet $\mathrm{BH}$ (compared with the average excretion with diets $\mathrm{B}$ and $\mathrm{H}$ ) were close to those of bacteria isolated from faeces of pigs fed on a standard diet (Laplace et al. 1985a) as shown by $\chi^{2}$ distance $\left(\chi^{2}=59\right)$, calculated according to Guilloteau et al. (1983). In contrast, they were different $\left(\chi^{2}=383\right)$ from that of total faeces of germ-free pigs, taken as an endogenous reference (Laplace et al. 1985a). Accordingly, the negative interaction in pigs fed on diet $\mathrm{BH}$ would result from a stimulated bacterial growth, under several complex influences. Among these, one could consider an increased retention of wheat-bran residues due to some decrease in the rate of passage in the presence of soya-bean hulls (Stanogias \& Pearce, $1985 a)$.

In contrast to protein and amino acids, there was no interaction between fibre sources on the digestibility of the other dietary constituents (energy, fibrous components) irrespective of the site of digestibility measurement. Furthermore, as expected from the literature (Keys \& De Barthe, 1974), the magnitude of the difference between diets was larger in the case of overall digestibility. This suggests that overall digestibility provides a 
better discrimination between diets for energy utilization than does ileal digestibility, due to the positive contribution of the hind-gut to fibre digestion.

The comparison of the digestibility coefficients of fibrous components (crude fibre, NDF, ADF) in the dietary treatments shows a higher disappearance of fibre in soya-bean hulls than in wheat bran, especially for the ADF (or lignocellulose) fraction. This is in agreement with previous results obtained in this laboratory (J. M. Pérez, unpublished results) or in the literature (Stanogias \& Pearce, $1985 a-c$ ). It is noteworthy that the digestibility of the NDF fraction in pigs fed on diet $\mathbf{H}$ (soya-bean hulls) reached a relatively high value $(0.15)$ at the end of the small intestine, and this is in agreement with recent findings (Lin et al. 1987).

From the results of the present study, as well as from the literature, there is no doubt that amino acid digestibility should preferably be measured at the distal end of the small intestine, while energy utilization may be measured at both faecal and ileal levels, in order to assess the partition of digestion between the small and large intestines. But positive or negative interactions between dietary components are likely to occur, depending on the type of fibre sources, their proportions and their associations in the diet. Therefore, the reported effects only refer to the specified fibrous materials used in the experiment. The general occurrence of interactions between the site of digestibility measurement and the dietary treatments, except for lysine, histidine and proline, is evidenced by the fact that the difference in digestibilities between the two sites varies considerably with the type of diet, although in a non-linear fashion. Consequently, the extrapolation from one to the other mode of digestibility measurement may be misleading.

The present work was supported by a grant from INRA for a coordinated programme on the utilization of fibrous materials by farm animals.

The authors thank Mesdames Françoise Bernard, Annick Blanchard, Michèle Dorléans, Sylvette Gougis and Nadine Mèzière for their skilled technical and surgical assistance. They are also grateful to Mesdames Jeanine Jung and Régine Calmes for amino acid analysis, to Messieurs Y. Lebreton, J. P. Prigent and A. Roger for the care of the animals, and to Madame Nadine Mandran for her helpful statistical advice. They thank Monsieur J. L. Barry and Madame Christine Hoebler from INRA-Nantes for cell wall components analysis of the fibre sources and Dr A. G. Low (AFRC, IGAP, Shinfield) for his critical evaluation of the manuscript and advice.

\section{REFERENCES}

Argenzio, R.A. \& Southworth, M. (1975). Sites of organic acid production and absorption in the gastrointestinal tract of the pig. American Journal of Physiology 228, 454-460.

Bardon, T. \& Fioramonti, J. (1983). Nature of the effects of bran on digestive transit time in pigs. British Journal of Nutrition 50, 685-690.

Collings, G. F., Erickson, J. P., Yokoyama, M. T. \& Miller, E. R. (1979). Effect of wheat middlings on fiber digestibility, serum cholesterol and glucose, and fecal bile acids in pigs. Journal of Animal Science 49 , $528-534$.

Dierick, N., Verkaeke, I., Decuypere, J. \& Henderickx, H. K. (1983). Influence de la nature et du niveau des fibres brutes sur la digestibilité iléale et fécale apparente de la matière sèche, des protéines et des acides aminés, et sur la rétention azotée chez les porcs. Revue de T Agriculture 36, 1691-1712.

Drochner, W. (1984). Einfluss wechselnder Rohfaser und Pektingehalte im Futter auf einige praecaecale und postileale Verdauungsvorgänge beim wachsenden Schwein. Fortschritte in der Tierphysiologie und Tierernährung no. 14. Hamburg: Verlag Paul Parey.

Ecknauer, R., Sircar, B. \& Johnson, L. (1981). Effect of dietary bulk on small intestinal morphology and cell renewal in the rat. Gastroenterology $81,781-786$.

Ehle, F. R., Jeraci, J. L., Robertson, J. B. \& Van Soest, P. J. (1982). The influence of dietary fiber on digestibility, rate of passage and gastrointestinal fermentation in pigs. Journal of Animal Science 55, 1071-1081.

El Rayah, A. A. \& Labavitch, J. M. (1977). A simplified method for accurate determination of cell-wall uronide content. Journal of Food Biochemistry 1, 361-365. 
Fioramonti, J. \& Bueno, L. (1980). Motor activity in the large intestine of the pig related to dietary fibre and retention time. British Journal of Nutrition 43, 155-162.

Giger, S., Darcy-Vrillon, B., Mandran, N. \& Duby, C. (1987a). Elaboration d'une méthode de test d'interaction digestive entre les composants du régime chez les animaux monogastriques. Annales de Zootechnie 36, $411-420$.

Giger, S. \& Sauvant, D. (1983). Comparaison de différentes méthodes d'évaluation du coefficient d'utilisation digestive des aliments concentrés par le ruminant. Annales de Zootechnie 32, 215-246.

Giger, S., Thivend, P., Sauvant, D., Dorléans, M. \& Journaix, P. (1987b) Etude de l'influence préalable de différentes enzymes amylolytiques sur la teneur en résidu NDF d'aliments du bétail. Annales de Zootechnie 36, $39-48$.

Graham, H., Hesselman, K. \& Aman, P. (1986). The influence of wheat bran and sugar beet pulp on the digestibility of dietary components in a cereal-based pig diet. Journal of Nutrition 116, 242-251.

Guilloteau, P., Sauvant, D. \& Patureau-Mirand, P. (1983). Methods of comparing amino acid composition of proteins: application to undigested proteins in the preruminant calf. Annals of Nutrition and Metabolism 27, $457-469$.

Imoto, S. \& Namioka, S. (1978). VFA production in the pig large intestine. Journal of Animal Science 47, $467-478$.

Institut National de la Recherche Agronomique (1984). L'alimentation des Animaux Monogastriques: Porc, Lapin, Volailles. Paris: INRA.

Jacobs, L. R. (1983). Effects of dietary fiber on mucosal growth and cell proliferation in the small intestine of the rat: a comparison of oat bran, pectin, and guar with total fiber deprivation. American Journal of Clinical Nutrition 37, 954-960.

Jacobs, L. R. \& Schneeman, B. O. (1981). Effects of dietary wheat bran on rat colonic structure and mucosal cell growth. Journal of Nutrition 111, 798-803.

Kass, M. L., Van Soest, P. J. \& Pond, W. G. (1980a). Utilization of dietary fiber from alfalfa by growing swine. (2) Volatile fatty acid concentrations in and disappearance from the gastrointestinal tract. Journal of Animal Science 50, 192-197.

Kass, M. L., Van Soest, P. J., Pond, W. G., Lewis, B. \& McDowell, R. E. M. (1980 b). Utilization of dietary fiber from alfalfa by growing swine. (1) Apparent digestibility of diet components in specific segments of the gastrointestinal tract. Journal of Animal Science 50, 176-191.

Keys, J. E. \& De Barthe, J. V. (1974). Site and extent of carbohydrate, dry matter, energy and protein digestion and the rate of passage of grain diets in swine. Journal of Animal Science 39, 57-62.

Kuan, K. K., Stanogias, G. \& Dunkin, A. C. (1983). The effect of proportion of cell-wall material from lucerne leaf meal on apparent digestibility, rate of passage and gut characteristics in pigs. Animal Production 36, 201-209.

Langlois, A., Corring, T. \& Février, C. (1987). Effects of wheat bran on exocrine pancreas secretion in the pig. Reproduction, Nutrition, Développement 27, 929-939.

Laplace, J. P. (1975). Small bowel resections: exhaustive approach to a theory of adaptation. World Review of Nutrition and Dietetics 23, 1-224.

Laplace, J. P. (1981). The transit of digesta in the different parts of the digestive tract of the pig. In Nutrition in Health and Disease and International Development. Progress in Clinical and Biological Research, vol. 77, pp. 847-872 [A. E. Harper and G. K. Davis, editors]. New York: Alan Liss.

Laplace, J. P., Darcy-Vrillon, B., Duval-Iflah, Y. \& Raibaud, P. (1985a). Proteins in the digesta of the pig: amino acid composition of endogenous, bacterial and fecal fractions. Reproduction, Nutrition, Développement 25, 1083-1099.

Laplace, J. P., Darcy-Vrillon, B. \& Picard, M. (1985 b). Evaluation de la disponibilité des acides aminés: choix raisonné d'une méthode. Journées de la Recherche Porcine en France 17, 353-370.

Lin, F. D., Knabe, D. A. \& Tanksley, T. D. (1987). Apparent digestibility of amino acids, gross energy and starch in corn, sorghum, wheat, barley, oat groats and wheat middlings for growing pigs. Journal of Animal Science 64, 1655-1663.

Low, A. G. (1982). Digestibility and availability of amino acids from feedstuffs for pigs: a review. Livestock Production Science 9, 511-520.

Low, A. G. (1985). Role of dietary fibre in pig diets. In Recent Advances in Animal Nutrition, pp. 87-112 [W. Haresign and D. J. A. Cole, editors]. London: Butterworths.

Murray, A. G., Fuller, M. F. \& Pirie, A. R. (1977). The effect of fibre in the form of various polysaccharides on the apparent digestibility of protein in the pig. Animal Production 24, 139 Abstr.

Pion, R. \& Fauconneau, G. (1966). Les acides aminés des protéines alimentaires. Méthodes de dosage et résultats obtenus. In Cahiers de I $A E C$ no. 6, pp. 155-175 [M. Vigneron, editor]. Commentry: AEC.

Rainbird, A. L. (1986). Effect of guar gum on gastric emptying of test meals of varying energy content in growing pigs. British Journal of Nutrition 55, 99-109.

Rainbird, A. L. \& Low, A. G. (1986a). Effect of guar gum on gastric emptying in growing pigs. British Journal of Nutrition 55, 87-98.

Rainbird, A. L. \& Low, A. G. (1986b). Effect of various types of dietary fibre on gastric emptying in growing pigs. British Journal of Nutrition 55, 111-121. 
Rotenberg, S., Eggum, B. O., Hegedus, M. \& Jacobsen, I. (1982). The effect of pectin and microbial activity in the digestive tract on faecal excretion of amino acids, fatty acids, thiamin, riboflavin, and niacin in young rats. Acta Agriculturae Scandinavica 32, 309-319.

Saeman, J. F., Moore, W. E., Mitchell, R. L. \& Millet, M. A. (1954). Techniques for the determination of pulp constituents by quantitative paper chromatography. Technical Association of the Pulp and Paper Industry 37, $336-343$.

Sambrook, I. E. (1979). Studies on digestion and absorption in the intestines of growing pigs. (8) Measurements of the flow of total lipid, ADF and VFA. British Journal of Nutrition 42, 279-287.

Sawardeker, J. S., Sloneker, J. H. \& Jeanes, A. (1965). Quantitative determination of monosaccharides as their alditol acetates by gas-liquid chromatography. Analytical Chemistry 37, 1602-1604.

Schneeman, B. O., Richter, B. D. \& Jacobs, L. R. (1982). Response to dietary wheat bran in the exocrine pancreas and intestine of rats. Journal of Nutrition 112, 283-286.

Snedecor, G. W. \& Cochran, W. G. (1967). Statistical Methods, 6th ed. Ames, Iowa: lowa State University Press.

Stanogias, G. \& Pearce, G. R. (1985a). The digestion of fibre by pigs. (1) The effects of amount and type of fibre on apparent digestibility, nitrogen balance and rate of passage. British Journal of Nutrition 53, 513-530.

Stanogias, G. \& Pearce, G. R. (1985b). The digestion of fibre by pigs. (2) Volatile fatty acid concentrations in large intestine digesta. British Journal of Nutrition 53, 531-536.

Stanogias, G. \& Pearce, G. R. (1985c). The digestion of fibre by pigs. (3) Effects of the amount and type of fibre on physical characteristics of segments of the gastrointestinal tract. British Joumal of Nutrition 53, 537-548.

Tanksley, T. D. \& Knabe, D. A. (1984). Ileal digestibilities of amino acids in pig feeds and their use in formulating diets. In Recent Advances in Animal Nutrition, pp. 75-95 [W. Haresign and D. J. A. Cole, editors]. London: Butterworths.

Van Soest, P. J. (1963). Use of detergents in the analysis of fibrous feed. (2) A rapid method for the determination of fiber and lignin. Journal of the Association of Official Analytical Chemists 46, 829-835.

Van Soest, P. J. \& Wine, R. H. (1967). Use of detergents in the analysis of fibrous feed. (4) Determination of plant cell-wall constituents. Journal of the Association of Official Analytical Chemists 50, 50-55.

Varel, V. H. (1987). Activity of fiber-degrading microorganisms in the pig large intestine. Journal of Animal Science 65, 488-496.

Varel, V. H., Pond, W. G. \& Yen, J. T. (1984). Influence of dietary fiber on the performance and cellulase activity of growing-finishing swine. Journal of Animal Science 59, 388-393. 